\title{
ANALISIS KESALAHAN PENGGUNAAN SINONIMI KATA KERJA DALAM KALIMAT BAHASA TIONGHOA PADA MAHASISWA SASTRA TIONGHOA UNIVERSITAS KRISTEN PETRA 彼得拉基督教大学中文系学生对汉语句子里近义动词用 法的偏误分析
}

\author{
Melisia Salim \\ Alpin Gadman Markali, S.S., M.A. \& Liejanto Wijaya, S.T. \\ Program Studi Sastra Tionghoa Universitas Kristen Petra, \\ Siwalankerto 121-131, Surabaya 60236 \\ E-mail: melisiasalim@gmail.com, \\ alpinli.88@gmail.com dan loliejanto@gmail.com
}

\begin{abstract}
ABSTRAK
Penelitian ini dilakukan untuk menganalisis jenis kesalahan dan penyebab kesalahan dalam menggunakan sinonimi kata kerja ke dalam kalimat bahasa Tionghoa pada mahasiswa Program Studi Sastra Tionghoa angkatan 2015, Universitas Kristen Petra Surabaya.

Pada proses pembelajaran seringkali timbul kesalahan dalam memadukan objek serta kegunaannya dari sinonimi kata kerja bahasa Tionghoa dalam kalimat, sehingga mendorong penulis untuk menganalisis lebih lanjut terhadap kesalahan penggunaan serta penyebabnya yang didasarkan pada teori sinonim bahasa Tionghoa oleh Xing dan Wang (2009).

Data penelitian didapat dari tes dan wawancara. Hasil analisis tes menunjukkan bahwa subjek penelitian masih belum dapat dengan baik menentukan sasaran objek dari sinonimi tersebut apakah diikuti objek benda atau manusia. Melalui wawancara juga diketahui kesalahan didominasi oleh kesalahan interlingual. Kesalahan ini semakin jelas terlihat saat siswa menterjemahkan sinonimi bahasa Tionghoa ke dalam bahasa Indonesia dengan tidak memperhatikan batasan objek sehingga timbul kesalahan. Faktor lain datang dari siswa melakukan overgeneralisasi, mengabaikan kaidah bahasa, penerapan kaidah yang kurang sempurna, faktor dari materi pengajaran dan pengajar serta dari diri siswa.

Dapat diketahui bahwa penggunaan dari sinonimi kata kerja bahasa Tionghoa masih terdapat kesulitan, selain memiliki kemiripan makna, penggunaannya juga tidak semua dapat saling menggantikan, hal ini yang dapat mengakibatkan terjadinya kesalahan penggunaan.
\end{abstract}

Kata kunci: Sinonimi kata kerja, analisis kesalahan, bahasa Tionghoa. 


\section{摘要}

此项研究进行为知道彼得拉基督教大学中文系 2015 届学生在句子里使 用近义动词的偏误类型与偏误原因分析。

在学习的过程中, 学生在句子搭配某些近义动词的对象与近义动词的 功能经常出错, 因此促动笔者再进一步调查近义动词的功能方面, 本文的主 要理论是依刑福义和汪国胜（2009）的汉语同义词理论。

本文通过测试及访谈调查法获取信息。据测试分析可看出, 学生还不 能正确使用近义动词, 尤其是搭配某近义动词的对象是人或物。通过访谈便 得知, 偏误主要出现是因为受了母语的影响, 学生把近义动词翻译成印尼语 忽视了词汉语中的规则局限而产生偏误。其他因素来自学生过度概括、忽视 规则局限性、不完全规则运用，也来自教材、教师与学生个人因素。

由此得知, 近义动词的用法存在着难点, 除了意思相近, 而且不都词 可以相互代替，因此用法上还经常出错。

关键词：近义动词、偏误分析、汉语 


\section{PENDAHULUAN}

Dalam mempelajari bahasa Tionghoa sebagai bahasa kedua tentu tidak mudah karena munculnya banyak hambatan dalam proses pembelajarannya adalah sesuatu yang tak terhindarkan. Salah satu hambatan ada pada dalam penggunaan sinonim dan sinonimi. Sinonim adalah sekelompok kata yang memiliki arti yang sama dan saling menggantikan sedangkan sinonimi, menurut kamus besar bahasa Indonesia (n.d), memiliki arti hubungan antara bentuk bahasa yang mirip atau sama maknanya.

Penggunaan sinonim dan sinonimi juga sangat diperlukan dalam berkomunikasi baik secara lisan maupun tulisan. Dengan menggunakan sinonim dan sinonimi dapat mengutarakan siratan, pengandaian, gaya bahasa serta warna bahasa yang berbeda, selain itu dapat dijadikan penekanan dalam berbahasa, dan yang terpenting jika penggunaannya bergantian dapat membuat bahasa kaya dengan kata-kata serta menghindari dari pengulangan kata-kata tertentu dalam mengutarakan pandangan atau isi hati yang dapat menimbulkan rasa jenuh baik bagi pendengar maupun pembaca (Xing \& Wang, 2009). Namun, permasalahan lain akan timbul jika penggunaannya tidak tepat dalam suatu konteks kalimat atau pembicaraan.

Karena sinonim memiliki keseluruhan arti yang sama, penggunaannya dalam kehidupan sehari-hari baik dalam bentuk lisan maupun tulisan tidak memiliki kesulitan yang berarti. Namun penggunaan sinonimi yang salah dimana kelompok kata tersebut masih memiliki perbedaan makna yang dekat, akan memberikan dampak yang besar dalam pembentukan kalimat.

Penggunaan sinonimi kata kerja bahasa Tionghoa sangat krusial karena ketika diaplikasikan di dalam konteks kalimat tertentu, maka akan memiliki perbedaan makna, perbedaan manfaat dan penggunaan dalam kalimat, apakah dapat dipadukan dengan objek manusia, benda atau lainnya, dapat membawa emosi dan perasaan baik berkonotasi positif maupun negatif (Xing \& Wang, 2009). Oleh karena itu, tidak semua sinonimi dapat saling menggantikan satu sama lain. Jika penggunaannya tidak tepat maka dapat melanggar kaidah-kaidah bahasa dan tidak menutup kemungkinan timbul kesalahpahaman.

Pada proses pembelajaran seringkali timbul kesalahan saat membuat kalimat terutama kesalahan yang diakibatkan tidak tepatnya memadukan sasaran objek dari suatu sinonimi dan kegunaannya di dalam kalimat. Untuk mengetahui lebih lanjut mengenai jenis kesalahan dan penyebabnya, dalam penelitian ini penulis melakukan penelitian pada Mahasiswa Universitas Kristen Petra Program Studi Sastra Tionghoa angkatan 2015. Pemilihan subjek penelitian dilatarbelakangi oleh mahasiswa angkatan tersebut telah menempuh proses belajar lebih dari dua tahun sedangkan masa perkuliahan diselesaikan dalam waktu empat tahun. Hal ini dapat menggambarkan bahwa subjek penelitian telah mempelajari banyak kosakata termasuk telah menemukan banyak sinonimi, terutama sinonimi kata kerja bahasa Tionghoa.

Penelitian sebelumnya yang dilakukan oleh Jureynold (2014) mengkaji pemahaman pembelajar Indonesia terhadap sinonimi kata adverbial bahasa Tionghoa, kemudian diikuti oleh Hong (2016) yang mengkaji penguasaan pembelajar dalam lima macam jenis sinonim bahasa Tionghoa. Dari kedua penelitian yang pernah dilakukan sebelumnya ini, penelitian pertama mengkaji 
jenis kata adverbial dan bukan kata kerja, sedangkan yang penelitian yang kedua sinonimi yang dikaji tidak terfokus pada satu jenis sinonim dan pada satu jenis kata, terlebih lagi data yang diperoleh diolah dengan menggunakan program SPSS dengan pendekatan kuantitatif. Hal ini mendorong penulis untuk secara khusus meneliti perbedaan manfaat dan penggunaan dari sinonimi kata kerja Bahasa Tionghoa.

\section{KAJIAN PUSTAKA Sinonim Bahasa Tionghoa}

Xing \& Wang (2009) menyatakan bahwa sinonim adalah kelompok kata yang menunjuk pada arti yang sama atau yang mendekati. Kata sinonim yang ketat adalah kata sinonim yang keseluruhannya memiliki arti yang sama sedangkan yang dimaksud dengan kata sinonim yang lebih luas adalah kelompok kata yang bertujuk pada konsep arti yang sama tetapi masih ada sedikit perbedaan (p. 200).

Xing \& Wang (2009) juga mengatakan mengatakan sinonim adalah kelompok kata yang menunjuk keseluruhan arti yang sama atau yang mendekati (sinonimi) yang dapat dibedakan sebagai berikut (pp. 200-203).

(1) Perbedaan makna

a. lingkup yang berbeda misal: “品质” (p̌nzhi) — “性质” (xingzhi) keduanya memiliki makna 'sifat', tetapi “品质” (pǐnzhi) lingkup maknanya lebih kecil karena untuk sifat manusia dan benda, sedangkan “性质” (xingzhi) lingkup makna lebih besr karena dapat digunakan untuk segala sesuatu

b. derajat makna berbeda misal: “损坏” (sǔnhuài) — “毁坏” (huǐhuài) keduanya bermakna 'merusak', namun “损坏” (sǔnhuài) derajat merusaknya lebih ringan dibandingkan dengan “毁坏” (huǐhuài).

c. titik berat sasaran yang berbeda misal: “美满” (měimăn) — “圆满” (yuánmăn) keduanya memiliki makna 'puas', namun “美满” (měimăn) dititikberatkan pada kepuasan kehidupan keluarga, sedangkan “圆满” (yuánmăn) menitikberatkan kepuasan untuk jawaban, hasil.

(2) Perbedaan manfaat dan penggunaan

a. berdasarkan sasaran yang dipadukan

Zhang (2014) Dalam menentukan sasaran yang tepat dari suatu sinonimi kata kerja dapat diperhatikan dari sinonimi tersebut bisa tidaknya diikuti oleh objek lain, jika dapat diikuti objek, apakah objek tersebut boleh diikuti objek yang konkret atau abstrak, objek manusia atau benda, tempat atau waktu dan sebagainya (p. 29).

Misal: “侵犯” (qīnfàn) — “侵犯” (qīnfàn) keduanya memiliki makna 'menduduki wilayah orang lain', tetapi “侵犯” (qīnfàn) biasanya dipadukan dengan hak, keuntungan, wilayah. “侵犯” (qīnfàn) biasanya dipadukan dengan tanah, harta, dan juga teritori.

Berdasarkan sinonimi kata kerja yang telah dipelajari, penulis menemukan tiga kelompok besar antara lain: (1) dapat tidaknya diikuti objek, (2) 
sasaran kata untuk manusia atau benda dan (3) diikuti objek konkret atau abstrak.

b. jenis kata dan manfaat dalam kalimat

sering dijumpai bahwa kata sinonim bahasa Tionghoa memiliki kegunaan yang sama dalam kalimat, misalnya “损坏” (sǔnhuài) dan “毁坏” (huǐhuài) keduanya dapat menjadi predikat, dan kata sifat. Namun ada juga kata sinonim yang meskipun memiliki jenis kata yang sama, tetapi kegunaannya dalam kalimat berbeda, misalnya “充分” (chōngfèn) dan “充 足” (chōngzú), kedua kata ini dapat menjadi atribut tetapi “充分” (chōngfèn) juga dapat menjadi adverbia. Jika jenis kata dari kata sinonim berbeda, dapat dipastikan bahwa kegunaannya dalam kelimat juga berbeda, misalnya, “永久” (yǒngjiǔ) dan “永远” (yǒngyuăn), “永久” (yǒngjiǔ) adalah kata sifat, sering dijadikan atribut, sedangkan “永远” (yǒngyuăn) adalah kata bantu kata kerja, sering dijadikan adverbia.

(3) Perbedaan emosi perasaan

Ada kata sinonim yang makna dasarnya sama namun warna emosinya berbeda, ada yang negatif dan juga yang positif serta ada yang berbeda dalam bahasa tertulis dan lisan.

Misal: “行为” (xíngwéi) — “行径” (xíngjìng) keduanya bermakna tindakan, tetapi “行为” (xíngwéi) bermakna positif sedangkan “行径” (xíngjing) bermakna negatif.

Terkadang dalam suatu kelompok sinonimi, jika dilihat dari arti kata terlihat dapat saling menggantikan satu sama lain, namun saat setelah diaplikasikan ke dalam kalimat, hasil penggunaan sinonimi yang telah disubstitusi satu sama lain tersebut terdapat kesalahan. Model kesalahan seperti ini tercermin dalam jenis sinonim bahasa Tionghoa perbedaan manfaat dan penggunaan yang terbagi atas: (1) berdasarkan sasaran yang dipadukan dan (2) jenis kata dan manfaat dalam kalimat yang merupakan inti dalam penelitian ini.

\section{Analisis Kesalahan}

Corder (1987) menyatakan ada 5 tahap dalam melakukan analisis kesalahan, yang pertama adalah mengumpulkan data kesalahan, pengidentifikasian kesalahan dan pengklasifikasian kesalahan, mengetahui penyebab kesalahan, mengevaluasi kesalahan, dan mengetahui tingkat keseriusan kesalahan. Parera (1997) juga mengatakan dalam menganalisis kesalahan dilaksanakan dengan beberapa langkah, diantaranya adalah pengumpulan data dari karangan siswa atau hasil dari ujian, lalu mengidentifikasi baik klasifikasi atau pengelompokkan kesalahan, pernyataan tentang frekuensi tipe kesalahan, identifikasi lingkup tipe kesalahan dan usaha perbaikan.

\section{Penyebab Kesalahan}

Richards (1971) mengatakan ada dua kemungkinan seseorang melakukan kesalahan berbahasa, antara lain:

(1) Terpengaruh bahasa yang lebih dulu dikuasainya. 
Dapat berarti bahwa kesalahan berbahasa dapat disebabkan oleh interferensi bahasa pertama terhadap bahasa target yang sedang dipelajari pembelajar. Dengan kata lain sumber kesalahan terletak pada perbedaan sistem linguistik bahasa pertama dengan sistem linguistik bahasa target. Kesalahan ini juga disebut kesalahan interlingual.

(2) Kekurang pahaman pemakai bahasa terhadap bahasa yang dipakainya.

Kesalahan yang merefleksikan ciri-ciri umum kaidah bahasa yang dipelajari. Dengan kata lain, salah atau keliru menerapkan kaidah bahasa, kesalahan ini juga disebut sebagai kesalahan intralingual. Kesalahan intralingual terdapat empat macam, antara lain:

a. overgeneralization, kesalahan yang disebabkan oleh generalisasi unsurunsur bahasa target secara berlebihan, mencakup contoh-contoh dimana seorang pelajar menciptakan struktur yang menyimpang yang didasarkan pada pengalamannya mengenai struktur-struktur lain dalam bahasa target.

b. ignore of rule restriction, kesalahan yang disebabkan oleh pembelajar mengabaikan pembatasan kaidah-kaidah bahasa target. Pembelajar gagal mengamati pembatasan-pembatasan dari struktur yang ada. Chen (2015) dalam Theory and Practice of Contemporary Education membagi lagi klasifikasi kesalahan atas mengabaikan kaidah-kaidah bahasa bahasa Tionghoa menjadi:

(a) mengabaikan batasan sasaran yang dipadukan dalam kalimat, terdapat beberapa kata yang hanya dapat dipadukan dengan kata tertentu. Mengabaikan kaidah ini dapat menimbulkan kesalahan.

(b) mengabaikan batasan jenis kata dalam kalimat, terdapat beberapa kata tertentu yang jika diaplikasikan ke dalam kalimat memiliki kegunaan yang berbeda. Mengabaikan kaidah ini dapat menimbulkan kesalahan.

c. incomplete application of rules, kesalahan penerapan kaidah bahasa target yang tidak sempurna.

d. false concept hypothesized, kesalahan dalam membuat hipotesis terhadap konsep kaidah bahasa target.

Selain penyebab diatas, Setyawati (2010) juga mengatakan pangkal penyebab kesalahan berbahasa juga dapat berasal dari pengajaran bahasa yang kurang tepat atau kurang sempurna. Hal ini berkaitan dengan bahasa yang diajarkan atau yang dilatihkan dan cara pelaksanaan pengajaran. Bahan pengajaran menyangkut masalah sumber, pemilihan, penyusunan, pengurutan, dan penekanan. Cara pengajaran menyangkut masalah pemilihan teknik penyajian, langkah-langkah dan urutan penyajian, intensitas dan kesinambungan pengajaran, dan alat-alat bantu dalam pengajaran.

\section{METODE PENELITIAN}

Penelitian ini menggunakan pendekatan kualitatif, karena data yang disajikan bukan menggunakan angka, metode statistik atau hasil penghitungan komputer melainkan berupa kata-kata. Instrumen penelitian yang digunakan penulis berupa pemberian tes dilanjutkan dengan wawancara. Untuk mendapatkan informasi yang mendalam tentu harus dilakukan wawancara yang mendalam pula. Sesuai dengan Bungin (2007) yang mengatakan wawancara yang mendalam adalah suatu cara mengumpulkan data atau informasi dengan cara langsung bertatap muka 
dengan narasumber. Dalam penelitian ini, wawancara dilakukan dengan bertatap muka dengan narasumber, dengan maksud mendapatkan gambaran lengkap tentang topik yang penulis teliti.

\section{Pemberian Tes}

Tes berisi 60 butir soal yang terdiri dari 30 pasang jenis sinonim sasaran yang dipadukan yang terbagi atas tiga kelompok (1) dapat tidaknya diikuti objek (nomor soal 1, 9, 17, 25, 31, 35, 37, 39, 51, 57), (2) sasaran kata untuk manusia atau benda (nomor soal 3, 7, 11, 15, 21, 27, 33, 43, 49, 55) dan (3) diikuti objek konkret atau abstrak (nomor soal 5, 13, 19, 23, 29, 37, 41, 45, 53, 59), sedangkan 30 pasang lainnya adalah jenis sinonim jenis dan kegunaan dalam kalimat. Soal tes terbagi atas dua bagian, bagian pertama adalah memilih kosa kata, jawaban betul dinilai satu poin, sedangkan salah dinilai nol poin. Bagian kedua adalah menentukan benar dan salah, jawaban betul dinilai 1,5 poin dan jawaban salah nol poin, masingmasing bagian terdiri atas 30 butir soal. Kosakata tersebut diambil dari buku 《汉 语教程》(Hanyu Jiaocheng) jilid satu hingga enam yang ditulis oleh Yang Jizhou karena buku tersebut digunakan subjek penelitian dalam mempelajari bahasa Tionghoa, sedangkan soal tes diambil dari buku 《1700 对近义词语用法对比》 (1700 Dui Jinyi Ciyu Yongfa Duibi) yang ditulis oleh Yang Jizhou dan Jia Yongfen yang dikenal sebagai rekomendasi bagi pengajar dan pembelajar bahasa Tionghoa dalam menemukan perbedaan sinonimi bahasa Tionghoa yang satu dengan yang lain.

\section{Wawancara}

Dalam penelitian ini, sebelum dilangsungkan wawancara, penulis membuat kuisioner. Pembuatan kuisioner bertujuan untuk memandu penulis sebelum melakukan wawancara dengan mengetahui gambaran kasar terhadap sikap, pandangan narasumber terhadap sinonimi kata kerja bahasa Tionghoa dan dalam proses pembelajarannya. Pertanyaan wawancara yang ditanyakan sama dengan pertanyaan kuisioner yang telah dibagikan, namun digali lebih mendalam. Untuk mengetahui penyebab kesalahan dalam tes dari penggunaan sinonimi kata kerja bahasa Tionghoa, penulis akan melakukan pencarian data lebih lanjut dengan mengajukan pertanyaan yang mengarah pada jawaban salah dalam tes untuk mengetahui proses pengerjaan dari narasumber.

\section{ANALISIS}

\section{Analisis Tes}

Dari data hasil tes yang telah terkumpul, penulis menemukan bahwa penguasaan narasumber terhadap penguasaan sinonimi kata kerja bahasa kurang baik.

Untuk dapat melihat lebih jelas, penulis melakukan penguruan berdasarkan kesalahan dominan dari setiap soal yang ditunjukkan pada Tabel 1. berikut. 
Tabel 1. Hasil Peringkat Kesalahan Soal

\begin{tabular}{|c|c|c|c|c|c|}
\hline No. Soal & $\begin{array}{c}\text { Jumlah } \\
\text { Kesalahan }\end{array}$ & Sinonimi & No. Soal & $\begin{array}{c}\text { Jumlah } \\
\text { Kesalahan }\end{array}$ & Sinonimi \\
\hline 6 & 12 & 一定、肯定 & 20 & 6 & 发达、发展 \\
\hline 32 & 12 & 按照、根据 & 34 & 6 & 联络、联系 \\
\hline 59 & 12 & 珍惜、珍爱 & 42 & 6 & 代替、代表 \\
\hline 33 & 11 & 尊敬、尊重 & 24 & 5 & 必须、必需 \\
\hline 57 & 11 & 分别、告别 & 36 & 5 & 坚决、坚定 \\
\hline 49 & 10 & 培养、培育 & 4 & 5 & 事业、工作 \\
\hline 27 & 10 & 集合、集中 & 39 & 5 & 忍耐、忍受 \\
\hline 37 & 10 & 接受、接收 & 58 & 5 & 行为、行动 \\
\hline 55 & 10 & 关照、照顾 & 48 & 5 & 通过、经过 \\
\hline 9 & 9 & 帮忙、帮助 & 1 & 4 & 问好、问候 \\
\hline 13 & 9 & 整理、整顿 & 41 & 4 & 到达、达到 \\
\hline 15 & 9 & 抚养、抚育 & 56 & 4 & 对比、对照 \\
\hline 47 & 9 & 提问、询问 & 2 & 4 & 喜欢、爱好 \\
\hline 46 & 9 & 活泼、活跃 & 8 & 3 & 差别、区别 \\
\hline 11 & 8 & 忽视, 轻视 & 7 & 3 & 举行、举办 \\
\hline 23 & 8 & 扩展、扩大 & 16 & 3 & 意见、建议 \\
\hline 38 & 8 & 打算、计划 & 40 & 3 & 报仇、报复 \\
\hline 3 & 7 & 生产、产生 & 12 & 3 & 合适、适合 \\
\hline 10 & 7 & 抱歉、道歉 & 50 & 3 & 全部、所有 \\
\hline 25 & 7 & 运输、运送 & 22 & 3 & 艰苦、辛苦 \\
\hline 35 & 7 & 挤、拥挤 & 18 & 2 & 感到、感觉 \\
\hline 31 & 7 & 交际、交流 & 26 & 2 & 回想、回忆 \\
\hline 52 & 7 & 收成、收获 & 21 & 2 & 生长、成长 \\
\hline 54 & 7 & 普遍、普及 & 45 & 2 & 增进、增加 \\
\hline
\end{tabular}




\begin{tabular}{ll|llll}
5 & 6 & 获得、获取 & 28 & 2 & 答案、回答 \\
17 & 6 & 变换、变化 & 29 & 2 & 等待、等候 \\
19 & 6 & 确定、确认 & 30 & 1 & 愉快、高兴 \\
43 & 6 & 包含、包括 & 51 & 1 & 演出、表演 \\
53 & 6 & 争夺、争取 & 14 & 1 & 放松、轻松 \\
60 & 6 & 掌握、把握 & 44 & 1 & 预防、防止
\end{tabular}

Sinonim jenis berdasarkan sasaran yang dipadukan dicetak abu-abu, sedangkan sinonim jenis kata dan manfaat dalam kalimat dicetak tidak berwarna. Dapat diketahui, bahwa jumlah kesalahan tertinggi ada pada jenis sinonim jenis dan manfaat dalam kalimat untuk kata “一定、肯定” (yīding, kěndìng, “pasti”), “根据、 按照” (gēnjù, ànzhào, “berdasarkan”) sebanyak 12 kesalahan, kemudian diikuti dengan jenis sinonim sasaran yang dipadukan untuk kata “珍惜、珍爱” (zhēnxī, zhēn'ài, "menyayangi") juga sebesar 12 kesalahan. Dari tabel diatas juga bisa dilihat, soal tes yang memiliki jumlah kesalahan yang tinggi didominasi oleh jenis sinonim sasaran yang dipadukan dan jumlah kesalahan yang rendah didominasi oleh jenis sinonim jenis kata dan manfaat dalam kalimat.

Untuk mengetahui lebih mendalam terhadap kesalahan kesalahan soal yang dilakukan oleh narasumber, penulis menganalisis jawaban narasumber dengan pemakaian dari kata itu sendiri sebagai berikut.

Soal tes nomor 6 yaitu kelompok kata “一定、肯定” (yìdìng, kěndìng, "pasti”) memiliki jumlah kesalahan yang tinggi karena banyak narasumber mengatakan tidak dapat menemukan perbedaan antara “肯定 (kěnding) dan “一定” (yìding). Dengan menggunakan dasar berpikir bahasa ibu, narasumber langsung mengartikan kata tersebut ke dalam bahasa Indonesia tanpa memperhatikan kaidah yang ada di dalam bahasa Tionghoa.

Soal tes nomor 32 untuk kelompok kata “根据、按照” (gēnjù, ànzhào, “berdasarkan, bukti”), banyak narasumber langsung menterjemahkan “根据” (gēnjù) sebagai "berdasarkan" dalam bahasa Indonesia, sehingga narasumber beranggapan "berbicara harus ada berdasarkan", karena setelah diterjemahkan ke dalam bahasa Indonesia terdapat keanehan maka tidak sedikit narasumber mengatakan kalimat tersebut salah, terlebih lagi menurut narasumber “根据” (gēnjù) tidak dapat digunakan sebagai objek, hal ini sangat berkebalikan dengan kegunaan kata tersebut yang selain sebagai kata kerja juga bisa dijadikan kata benda.

Soal tes nomor 59 yaitu kelompok kata “珍惜、珍爱” (zhēnxī, zhēn'ài, "menyayangi") dalam pengerjaan soal tes juga banyak melakukan kesalahan. Narasumber langsung mengartikan kata “珍惜” (zhēnxī) sebagai “menyayangi” dalam bahasa Indonesia tanpa memperhatian kaidah bahasa Tionghoa. Objek dalam kalimat yaitu “孙子” (sūnzi) yang berarti “cucu”, sehingga lahirlah pemahaman “ 'menyayangi' cucu”. Pemahaman ini salah dikarenakan “珍惜” (zhēnxî) tidak dapat membawa objek yang konkret. 
Soal tes nomor 33, menurut narasumber penggunaan 尊敬 telah tepat karena jika diterjemahkan ke dalam bahasa Indonesia yaitu "menghormati sejarah" tidak terdapat keanehan dalam hasil terjemahannya. Namun saat menterjemahkan, narasumber tidak memperhatikan kaidah bahasa Tionghoa, hal ini sangat terlihat narasumber tidak memperhatikan objek yang diikuti kata “尊敬” (zünjìng) hanya dapat diikuti dengan objek manusia, sedangkan “历史” (lish ‘) yang berarti “sejarah" bukan objek manusia. Penulis juga menanyakan apa perbedaan antara “尊敬” (zünjìng) dan 尊重” (zünzhòng), narasumber mengatakan kedua kata tersebut memiliki jenis kata yang sama, yaitu kata kerja, sehingga tidak menemukan letak perbedaan dan penggunaannya.

Soal tes nomor 27 yaitu kelompok soal “集合、集中” (jíhé, jízhōng, “memusatkan”) tidak sedikit pula narasumber yang mengatakan memilih “集合” (jíhé) sebagai jawaban, selain karena pemakaian “集合” (jíhé) lebih sering digunakan dan lebih familiar, tetapi juga dikarenakan narasumber mengartikan “集 合” (jíhé) sebagai “kumpul” sedangkan “集中” (jízhōng) berarti “fokus” dalam bahasa Indonesia. Kemudian, jika melihat struktur kalimat, objek dari kalimat tersebut adalah “大家的力量和智慧” (dàjiā de lìliàng hé zhìhui) yang berarti "tenaga dan pikiran semua orang", oleh karenanya narasumber merasa hasil terjemahan "mengumpulkan tenaga dan pikiraen semua orang" akan lebih tepat dan masuk akal dibandingkan "memfokuskan tenaga dan pikiran semua orang". Dari sini dapat dilihat bahwa terjemahan narasumber tidak memperhatikan Batasan pemakaian kata “集合” (jíhé) sendiri, kata “集合” (jíhé) hanya diikuti oleh objek manusia sedangkan objek kalimat "tenaga dan pikiran" bukan objek manusia. Sehingga dapat diketahui narasumber mengabaikan batasan kaidah dalam bahasa Tionghoa.

Dari pemaparan analisis diatas, dapat diketahui jenis sinonim sasaran yang dipadukan memiliki kesalahan yang lebih banyak dibandingkan dengan jenis sinonim jenis kata dan manfaat dalam kalimat, khususnya pada kelompok sinonimi kata kerja yang diikuti oleh benda atau manusia. Diketahui pula terjadi kesalahan yang sistematik dan sama antara soal yang satu dengan soal yang lain, yaitu narasumber langsung mengartikan kelompok kata tersebut ke dalam bahasa Indonesia tanpa memperhatikan kaidah batasan objek bahasa Tionghoa.

\section{Hasil Wawancara}

Untuk mendapatkan data yang lebih mendalam, penulis melakukan wawancara secara acak kepada delapan narasumber, yaitu S2, S3, S8, S12, S1, S13, S5, dan S4. Dalam wawancara ditemukan dua jenis kesalahan, yaitu kesalahan interlingual dan intralingual, sedangkan faktor-faktor penyebab kesalahan penggunaan sinonimi kata kerja bahasa Tionghoa sebagai berikut. 
Tabel 2. Faktor Penyebab Kesalahan Narasumber

\begin{tabular}{|c|c|c|c|c|c|}
\hline $\begin{array}{c}\text { Terpengaruh } \\
\text { Bahasa yang } \\
\text { Dikuasai } \\
\text { Sebelumnya }\end{array}$ & $\begin{array}{c}\text { Over- } \\
\text { generalisasi }\end{array}$ & $\begin{array}{c}\text { Mengabaikan } \\
\text { Kaidah } \\
\text { Bahasa }\end{array}$ & $\begin{array}{c}\text { Penerapan } \\
\text { kaidah } \\
\text { bahasa } \\
\text { yang tidak } \\
\text { sempurna }\end{array}$ & $\begin{array}{r}\text { Faktor } \\
\text { Materi } \\
\text { Pengajaran } \\
\text { dan } \\
\text { Pengajar }\end{array}$ & $\begin{array}{r}\text { Faktor dari } \\
\text { siswa }\end{array}$ \\
\hline S1 & S8 & S1 & S1 & Pengajar & Hanya \\
\hline S2 & S4 & S2 & S13 & $\begin{array}{c}\text { kurang } \\
\text { inisiatif }\end{array}$ & $\begin{array}{l}\text { mengandalkan } \\
\text { kelas dalam }\end{array}$ \\
\hline S3 & S1 & S3 & S4 & $\begin{array}{r}\text { dalam } \\
\text { mengajarkan }\end{array}$ & $\begin{array}{r}\text { mempelajari } \\
\text { sinonimi, }\end{array}$ \\
\hline S4 & S3 & S4 & & $\begin{array}{r}\text { sinonimi } \\
\text { dalam kelas }\end{array}$ & $\begin{array}{l}\text { Kurangnya } \\
\text { kesadaran diri }\end{array}$ \\
\hline S5 & & S5 & & & \\
\hline S8 & & S8 & & & \\
\hline $\mathrm{S} 12$ & & $\mathrm{~S} 12$ & & & \\
\hline $\mathrm{S} 13$ & & $\mathrm{~S} 13$ & & & \\
\hline
\end{tabular}

\section{Terpengaruh Bahasa yang Dikuasai Sebelumnya}

Dalam wawancara yang dilakukan oleh penulis dengan narasumber, tidak sedikit dari mereka yang mengatakan bahwa ketika mengerjakan soal menggunakan pengetahuan dan pemikiran bahasa ibu (bahasa Indonesia) sebagai dasar berpikir untuk menjawab soal. Fenomena ini semakin terlihat ketika saat narasumber tidak memiliki pengetahuan yang cukup dalam terhadap suatu sinonimi terkait.

Seperti yang dilakukan S2, S4, dan S5, hal pertama yang dilakukan oleh adalah menterjemahkan sinonimi terkait ke dalam bahasa Indonesia dengan tidak memperhatikan kaidah dan batasan bahasa Tionghoa. Menurut S2, S3, S8, S5 dan S13, apabila saat diterjemahkan ke dalam bahasa Indonesia dalam pengertiannya terdapat keanehan maka penggunaan sinonimi terkait salah dalam kalimat, sedangkan jika tidak ditemukan keanehan dan masuk di akal, maka menurutnya penggunaan sinonimi tersebut sudah benar tepat sesuai konteks

\section{Overgeneralisasi}

Dari hasil wawancara dengan narasumber, banyak dari narasumber masih belum mengerti dengan jelas dimana letak perbedaan sinonimi kata kerja bahasa Tionghoa yang satu dengan sinonimi yang lain. Misalnya sinonimi “获取” (huòqǔ) dan “获得” (huòdé) menurut S8 tidak ada perbedaan penggunaan, begitu pula dengan S4 yang mengatakan “集合” (jíhé) dan “集中” (jízhōng), “抚养” (fǔyăng) dan “抚育” ( füyù) tidak memiliki perbedaan. Banyak dari narasumber mengatakan tidak menemukan perbedaan diantaranya dan sebagian besar mengatakan kedua 
sinonimi memiliki fungsi dan makna yang sama sehingga ketika diaplikasikan ke kalimat tidak ada perbedaan. Kesalahan yang disebabkan oleh faktor ini sangat telihat di tes bagian pertama yang memberikan dua pilihan sinonimi untuk disesuaikan dengan konteks dan struktur kalimat dengan tepat.

\section{Mengabaikan Batasan Sasaran yang Dipadukan}

Berdasarkan hasil wawancara dan analisis data, kesalahan jenis sinonim sasaran yang dipadukan jika dibandingan dengan jenis kata dan manfaat memiliki kesalahan yang tinggi, hal ini ditemukan banyak dari narasumber gagal bahkan tidak memperhatikan konteks dari kalimat yang diberikan terutama objek dari sinonimi itu sendiri, apakah kata kerja tersebut boleh atau tidak diikuti oleh objek dan lain sebagainya.

Sebagai contoh jawaban dari S12 dan S5 beranggapan bahwa kalimat kata “集合” (jíhé) sudah sangat sering digunakan sehingga narasumber tidak mempertimbangkan dan mengamati objek apa yang boleh atau tidak boleh diikuti. Namun, “集合” (jíhé) sendiri memiliki batasan objek yang telah diabaikan oleh narasumber.

Narasumber lebih memilih menggunakan perasaan bahasa, dengan melihat konteks kalimat kemudian dimasukkan sinonimi tersebut ke dalam kalimat yang didasarkan pada alunan nada kalimat, jika terdengar masuk akal dan terdengar familiar maka menurutnya penggunaan sinonimi tersebut telah tepat, begitu juga sebaliknya.

\section{Mengabaikan Batasan Jenis Kata dalam Kalimat}

Dari hasil analisis data memperlihatkan bahwa kesalahan sinonimi jenis dan manfaat dalam kalimat meskipun tidak sebanyak sinonimi jenis memadukan sasaran namun tetap menjadi hal yang diperhitungkan dalam penguasaan bahasa.

Dalam hasil wawancara ditemukan bahwa sebagaian besar narasumber tidak memperhatikan jenis kata dalam menentukan sinonimi dalam kalimat serta tidak memperhatikan fungsinya dalam kalimat. Misalnya jawaban dari S13 dan S4 yang mengatakan dalam menentukan sinonimi tidak melihat struktur kalimat namun menggunakan perasaan bahasa yang didasarkan pada alunan kalimat, jika terdengar masuk akal dan familiar maka menurutnya sinonimi tersebut penggunaannya telah tepat begitu juga dengan sebaliknya.

\section{Penerapan Konsep Kaidah yang Tidak Sempurna}

Selain penyebab kesalahan berasal dikarenakan mengabaikan kaidah bahasa, penyebab juga ada pada penerapan konsep kaidah yang tidak sempurna. Narasumber memiliki konsep dari penggunaan suatu sinonimi namun secara tidak menyeluruh. Dalam wawancara, penulis menanyakan perbedaan sinonimi yang satu dengan yang lain, misalnya dalam pemakaian “根据” (gēnjù) yang berarti “menurut" atau “berdasarkan”. Menurut S12, penggunaan “根据” (gēnjù) hanya sebagai kata kerja dan peletakkannya di awal kalimat, pernyataan ini sama dengan yang dikatakan S1 dan S4, mereka menambahkan bahwa kegunaannya tidak berfungsi sebagai objek dalam kalimat. Penjelasan para narasumber tidak sepenuhnya salah, namun yang harus digaris bawahi adalah pemakaian “根据”(gēnjù) juga bisa 
dijadikan objek dalam kalimat, pemakaian yang seperti ini tidak dimengerti oleh narasumber yang mengakibatkan kesalahan.

\section{Faktor Materi Pengajaran dan Pengajar}

Di dalam buku pengajaran bahasa Tionghoa yang sekarang digunakan, kebanyakan bagian kosakata dijelaskan menggunakan karakter bahasa Tionghoa, romanisasi bahasa Tionghoa (hanyu pinyin 汉语拼音) dan sedikit penjelasan bahasa Inggris sedangkan bagian lain dijelaskan dalam bahasa Tionghoa. Penggunaan bahasa Inggris bagi sebagian narasumber dirasa membantu dalam pembelajaran kosa kata karena juga ada beberapa kosakata yang akan lebih mudah dimengerti jika dijelaskan dalam bahasa Inggris, namun juga kurang membantu dalam mempelajari sinonimi, hal ini disebabkan karena satu sinonimi dengan sinonimi yang lain diartikan dengan kata yang sama. Selain itu di dalam buku juga tidak diberikan penjelasan perbandingan penggunaan sinonimi yang terkait dalam satu bab, sehingga siswa mengatakan bingung dalam menggunakan, terlebih lagi tertulis dengan arti yang sama membuat siswa semakin rancu dalam mengartikan, oleh karenanya siswa merasa butuh bimbingan dari pengajar.

Dari hasil wawancara diketahui, ketika siswa bertanya berkaitan dengan sinonimi yang tidak dimengerti, pengajar langsung memberikan penjelasan dengan menggunakan sinonimi yang telah dipelajari sebelumnya untuk menjelaskan sinonimi yang baru. Sebagai contoh, misalnya dalam menjelaskan “忽视” ( $h \bar{u} s h i)$ dan “轻视” (qingshi) yang berarti “mengabaikan”, pengajar seringkali menggunakan “轻视” (qingshi) dalam menjelaskan “忽视” (hüshi). Berdasarkan informasi yang didapatkan, penjelasan yang seperti ini terkadang membantu dan juga tidak, karena dengan menggunakan sinonimi terdahulu untuk menjelaskan sinonimi yang baru terkadang tidak diikuti dengan penjelasan lanjutan dari penggunaan sinonimi itu sendiri, apabila masih terdapat siswa yang bingung maka akan dijelaskan melalui contoh kalimat.

Contoh kalimat yang diberikan tidak banyak, disesuaikan dengan pemahaman siswa, apabila siswa sudah paham maka pengajar tidak memberikan contoh kalimat yang lain. Namun perlu diketahui bahwa hubungan sinonimi yang satu dengan yang lain tidak hanya memiliki satu sisi melainkan banyak sisi yang juga harus dijelaskan, dalam kalimat yang berbeda tentu memiliki sudut pandang dan sisi dari kegunaan sinonimi yang berbeda pula, apabila contoh yang diberikan terbatas dan hanya dari satu sisi tertentu saja, maka tentu akan memengaruhi pemahaman siswa yang berujung pada kesalahan.

Melalui wawancara diketahui bahwa sebagian besar narasumber merasa kesulitan dalam membedakan sinonimi yang memiliki karakter fonem yang sama dibandingkan yang berbeda. Melihat realita ini, maka sangat diperlukan penjelasan akan perbedaan fonem yang ada di antara sinonimi yang satu dengan sinonimi yang lain, namun sangat disayangkan cara ini jarang dan hampir tidak pernah diterapkan dalam proses pembelajaran. Penjelasan secara detil untuk setiap fonem akan sangat membantu, karena perbedaan fonem yang membentuk sinonimi adalah kunci perbedaan sinonimi itu sendiri, jika siswa mengerti kunci unsur pembentuk kata, maka juga dapat mengetahui arti kata dari makna unsur pembentuk kata itu sendiri sehingga siswa tidak hanya mengerti arti namun juga makna dari sinonimi tersebut. 


\section{Faktor dari Siswa}

Selain faktor-faktor penyebab kesalahan di atas tentu tidak terlepas dari faktor siswa itu sendiri. Seperti yang telah dijelaskan sebelumnya, hasil kuisioner menunjukkan bahwa lebih dari setengah dari total seluruh narasumber hanya mengandalkan kelas dalam mempelajari sinonimi, sehingga dapat diketahui bahwa siswa sangat bergantung pada kelas.

Dari wawancara, sebagian narasumber juga mengakui bahwa keterbatasan bahasa dan kosakata yang dimiliki juga menghambat dalam mengartikan maksud dari yang pengajar jelaskan. Penjelasan dari pengajar native tidak diserap seutuhnya karena keterbatasan kosakata dan bahasa yang dikuasai oleh siswa, sehingga jika isi penjelasannya menggunakan kata-kata diluar kemampuan dan pemahamannya maka penjelasan yang diterangkan tidak dapat diserap sepenuhnya, sedangkan penjelasan dari pengajar berbahasa ibu juga terdapat hambatan bahasa, karena sinonimi kata kerja bahasa Tionghoa itu sendiri susah untuk dijelaskan dengan bahasa Indonesia terlebih lagi mendapatkan kata yang tepat untuk mengartikan sinonimi tersebut sangat sulit sehingga membuat siswa semakin bingung.

Selain dipengaruhi faktor di atas, untuk mengurangi keterbatasan kosakata terutama sinonimi kata kerja bahasa Tionghoa, media kamus digunakan oleh siswa untuk menyelesaikan hambatan bahasa. Namun, dibandingkan melihat kamus yang berfisik atau referensi yang membahas lebih lanjut mengenai sinonimi terkait, siswa lebih memilih menggunakan media kamus elektronik Pleco ${ }^{1}$ untuk mencari arti kata dan sinonimi.

Siswa sangat menyadari bahwa kamus Pleco tidak cukup memberikan penjelasan yang lebih dalam dan rinci mengenai sinonimi, meskipun memiliki kelemahan, banyak yang mengatakan kepraktisan menjadi alasan utama menggunakan kamus elektronik sehingga jarang melihat referensi yang lain. Karena keterbatasan referensi yang digunakan, maka, baik banyak ataupun sedikit tetap mempengaruhi pemahaman siswa terhadap kosakata maupun sinonimi, hanya sebagian dari mereka melakukan penelusuran di Internet untuk penjelasan lebih lanjut.

Di dalam keadaan seperti ini, untuk mendapatkan penjelasan yang lebih jelas, beberapa siswa bertanya kepada temannya, hasil wawancara mengatakan bahwa pengetahuan teman atau siswa pun juga terbatas, hanya pada yang dirasa tertarik dan yang penting saja memiliki penjelasan yang lebih dalam. Jika sinonimi tersebut sekiranya akan sangat penting dan menarik dan sering digunakan akan diingat, jika tidak, sinonimi tersebut tidak akan pernah dipakai. Faktor ini juga menghambat memiliki penguasaan kosakata dan sinonimi terutama sinonimi kata kerja bahasa Tionghoa.

Lebih dari setengah dari total seluruh narasumber mengatakan bahwa sinonimi penting untuk dipelajari, namun tidak tercermin dari kesadaran diri siswa untuk melatih diri, banyak faktor yang mempengaruhi yang tidak hanya dari luar siswa tapi juga dari dalam diri siswa. Sebaik apapun pengajar dalam mengajarkan bahan ajaran namun jika tidak dimaknai dengan baik, maka pengajaran hanya seperti menabur biji di atas batu.

\footnotetext{
${ }^{1}$ Pleco: aplikasi kamus bahasa Inggris dan Mandarin yang tersedia dalam iOs maupun Android
} 


\section{KESIMPULAN}

Hasil analisis tes memperlihatkan kesalahan jenis sinonim sasaran yang dipadukan memiliki jumlah kesalahan yang lebih banyak dibandingkan dengan jenis sinonim manfaat dan kegunaan dalam kalimat, sehingga dapat disimpulkan bahwa siswa masih belum baik dalam menggunakan dan mengaplikasikan sinonimi kata kerja bahasa Tionghoa ke dalam kalimat terutama dalam memadukan sasaran sinonimi.

Dari hasil wawancara juga dapat disimpulkan bahwa kesalahan jenis interlingual sangat mendominasi, kesalahan jenis ini muncul dari pengaruh bahasa yang lebih dulu dikuasai oleh siswa. Siswa langsung mengartikan sinonim tersebut tanpa melihat batasan objek. Hal ini berkebalikan dengan jenis sinonim sasaran yang dipadukan yang sangat memperhatikan batasan objek yang dimiliki. Faktor ini yang menyebabkan kesalahan jenis sinonim sasaran yang dipadukan memiliki kesalahan yang lebih banyak dibandingkan dengan jenis sinonim manfaat dan kegunaan dalam kalimat.

Faktor lainnya yang mempengaruhi kesalahan adalah siswa melakukan overgeneralisasi, mengabaikan kaidah bahasa serta menerapkan kaidah yang tidak sempurna. Selain faktor diatas, dipengaruhi juga dari materi pengajaran dan pengajar serta dari diri siswa

Melihat hal ini, perlu diadakannya peningkatan kualitas pengajaran terutama penekanan terhadap pembelajaran sinonimi agar lebih efektif dan tepat sasaran. Tidak sedikit narasumber yang mengatakan bahwa kelompok sinonimi kata kerja bahasa Tionghoa yang memiliki karakter fonem yang sama lebih membingungkan dibandingkan dengan yang berbeda. Oleh karena itu selain dijelaskan menggunakan contoh kalimat, diharapkan pengajar juga dapat mengajarkan sinonimi dengan melakukan analisis fonem yang ada di dalam kelompok sinonimi tertentu, dengan demikian siswa dapat mengerti secara garis besar makna dasar yang terkandung dalam sinonimi tersebut.

Kesalahan sinonimi jenis sasaran yang dipadukan memiliki jumlah kesalahan yang lebih besar dibandingkan dengan sinonimi jenis kata dan manfaat dalam kalimat, oleh karena itu perlu dilakukan penekanan pengajaran dalam menentukan sasaran objek dari sinonimi kata kerja tertentu, terutama dalam menentukan objek manusia atau benda dari suatu sinonimi kata kerja. Pengajar juga dapat melakukan analisis penggunaan sinonimi kata kerja tertentu dilihat dari objek yang dapat diikuti dan tidak dari sinonimi kata kerja tersebut.

Agar analisis lebih mudah, objek sinonimi kata kerja dapat dijelaskan dengan menggunakan tabel, cara ini selain dapat mempermudah pengajar dalam menjelaskan, namun juga dapat mempermudah siswa lebih mengerti perbedaan objek yang diikuti oleh masing-masing sinonimi tertentu.

Penggunaan tabel juga dapat digunakan untuk memberikan penjelasan lebih lanjut terhadap kegunaan, jenis kata dan fungsi kelompok sinonimi dalam membentuk kalimat. Karena dikemas dengan ringkas yang langsung dibandingkan secara head to head, pengajar secara langsung atau tidak langsung telah memepermudah penjelasan teoritis yang terkadang tidak susah dipahami dan tidak mudah diingat. Agar pengajaran lebih optimal, pengajar selanjutnya dapat memberikan latihan seperti soal seperti soal mengisi, membetulkan kalimat yang salah dan lain-lain 
Namun usaha peningkatan pengajaran juga harus dibarengi dengan kesadaran siswa, kesadaran dapat dimulai dari sedapat mungkin mengaplikasikan penggunaan sinonimi yang dipelajari dalam kehidupan sehari-hari, dengan sering digunakannya sinonimi tersebut selain dapat memperkuat ingatan terhadap penggunaannya, tetapi juga dapat melatih perasaan bahasa ke tahap selanjutnya. Siswa juga diharapkan memiliki strategi pembelajaran yang tepat, sehingga dalam proses pembelajaran terutama dalam menganalisis sinonimi yang satu dengan yang lain, sekalipun sulit, namun dengan strategi belajar yang tepat dapat dimaknai sebagai suatu kenikmatan tersendiri.

Karena keterbatasan waktu dalam penyusunan penelitian ini, ditambah dengan kemampuan penulis yang juga terbatas, penelitian ini terdapat banyak ketidaksempurnaan. Penelitian ini hanya meneliti kemampuan siswa dalam menggunakan sinonimi kerja bahasa Tionghoa ke dalam kalimat yang terfokus pada penggunaan. Diharapkan peneliti selanjutnya dapat meneliti dari sudut pandang yang lain seperti perbedaan makna atau perbedaan emosi perasaan dengan jenis kata yang lain seperti kata sifat dan tidak terbatas pada kata kerja saja.

\section{DAFTAR PUSTAKA}

Chen Fan Fan. (2015). Yunei pianwu chengyin tanxi. Theory and Practice of Contemporary Education, vol. (7), pp. 105-108.

Hong Wei. (2016). Investigation of the difficulty level of five types of differences acquisition of chinese near synonyms. TCSOL Studies, vol. (2), pp. 10-18.

Luo Qing Song. (1997). Yingyu guojia xuesheng gaoji hanyu cihui xuexi guocheng de xinli tezheng yu jiaoxue celue. Di Wu Jie Guoji Hanyu Jiaoxue Taolunhui Lunwen Xuan. Beijing: Beijing Daxue Chubanshe.

Xing Fu Yi dan Wang Guo Sheng. (2009). Xiandai hanyu. Wuhan: Huazhong Shifan Daxue Chubanshe.

Yang Ji Zhou dan Jia Yong Fen. (2012). 1700 dui jinyi ciyu yongfa duibi. Beijing: Beijing Yuyan Daxue Chubanshe.

Zhang Jian Min. (2014). An analysis on the errors of acquiring near synonymous verb for south korean intermediate and advanced chinese learners. Unpublished postgraduate thesis, East China Normal University.

Corder, S.P. (1981). Error Analysis And Interlanguage. Oxford: Oxford University Press.

Ellis, R. (1987). Understanding Second Language Language Aacquistition. Oxford: Oxford University Press.

Jureynold. (2017). The analysis error of chinese frequency adverbs towards Indonesian learner. Hanyu Zuowei Di Er Yuyan Xide Yanjiu, vol. (14), pp. 752-765.

Kamus besar bahasa indonesia, (n.d). Sinonim. Retrieved May 5, 2017, from http://kbbi.web.id/sinonim

Kamus besar bahasa indonesia, (n.d). Sinonimi. Retrieved March 23, 2018, from http://kbbi.web.id/sinonimi

Richards, J. (1971). Error Analysis And Second Languages Strategies. Quebec: University Laval. 
Salim : Analisis Kesalahan Penggunaan Sinonimi Kata Kerja Dalam Kalimat Bahasa Tionghoa Pada Mahasiswa Sastra Tionghoa Universitas Kristen Petra

Setyawati, N. (2010). Analisis Kesalahan Berbahasa Indonesia: Teori Dan Praktik. Surakarta: Yuma Pustaka.

Sugiyono. (2008). Metode Penelitian Kuantitatif, Kualitatif Dan R\&D. Bandung: Alfabeta. 